\title{
WILLIAM F. CODY, BUFFALO BILL, AN IOWA-BORN FOLK HERO
}

\author{
By James M. Bentley
}

What do you think of when you hear the name William Frederick Cody? I first think of his nickname "Buffalo Bill" and then of his famous Wild West Show. But seldom do I think of Cody's Iowa birth and boyhood days.

I imagine to Mr. and Mrs. Roy Curtis and the "Save Our Landmarks Society" of the Quad-Cities, the name brings the Cody Homestead first to mind. About 20 years ago, Mr. Curtis bought the farm on which the Homestead is located and he and his wife have lived there ever since. Mr. Curtis has spent a great deal of time and money doing some interior refinishing and furnishing of the house. This past year he deeded the Homestead and surrounding property to the Quad-Cities" "Save Our Landmarks Society;" this society intends to completely renovate the buildings and grounds.

The people of LeClaire, Iowa, probably think first of The Buffalo Bill Museum, located in their town, when they hear the name "Cody." According to the Curator, Mrs. Harold Kennedy, The Buffalo Bill Museum was incorporated in June, 1957, "to promote and create interest in and to reconstruct and preserve early history, documents and relics pertaining to the Mississippi River, the Indian race, and William F. Cody (Buffalo Bill) who was born at the edge of (this) town."

The Museum was originally a project of the LeClaire Women's Club in a Community Achievement contest (19561958) sponsored by the General Federation of Women's Clubs and the Sears Roebuck Foundation; it received a Special Citation. Today, money for the operation and maintenance comes from memberships, donations and fund-raising projects. It has a membership of 100; it is managed by an executive board of twelve members, four of which are officers of the corporation. Charles C. Morgan is president of the Board; Mrs. Clarence Bowker, vice-president; Mrs. Frank Clark, recording secretary; and Mrs. Harold Kennedy, treasurer and Museum Curator. 
Among the Buffalo Bill items in the Museum are a minature "history of the bible" used by the Cody children while living at LeClaire; a grain cradle (scythe) owned and used by Isaac Cody, Father of Buffalo Bill, on his farms in LeClaire Township and later on his farm near Wapsie River; a milk glass sugar bowl of Mrs. Cody; a Winchester Rifle used in Cody's Wild West Show and various programs of the Show.

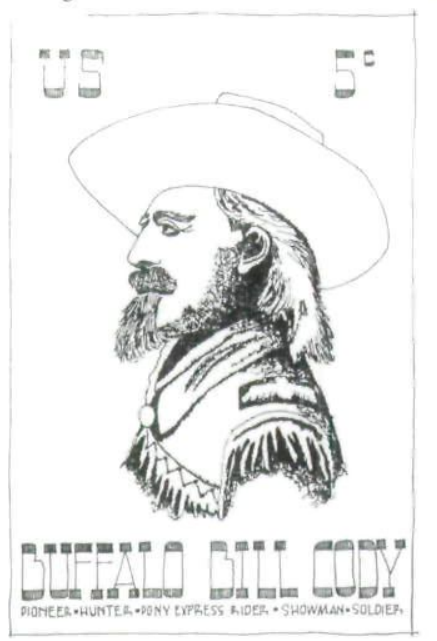

The following manuscript touches upon the many aspects of William F. Cody's life and interests. The aritcle was compiled for the purpose of helping to establish and justify the issuance of a United States postage stamp commemorating Buffalo Bill Cody. James M. Bentley, the author, has been active in his work for such a postage stamp and included here is a sketch by Mr. Bentley of a possible style for the stamp.

Two copies of the following article were sent to Fred Schwengel, U. S. Representative, First District, Iowa, in October, 1967; in the accompanying letter, Mr. Bentley wrote: "Many people from around the world know of his (Cody's) efforts on behalf of perpetuating the "Wild West." The issuance of a stamp commemorating Buffalo Bill would cause many people to dig deeper into his life and maybe learn a little about his activities as a herder, pony express rider, stage driver, wagon master, government scout and guide, railroad contractor, Indian fighter, soldier, justice of the peace, member of the legislature, farmer, stock raiser, irrigator, miner, showman, author and publisher. The formative activities of this man helped to lead to an understanding of Authentic Folk Hero out of America's past."

Rep. Schwengel, in turn, sent a copy of this manuscript to Lawrence O'Brien, Postmaster General; in his accompanying letter he wrote: "I heartily endorse Mr. Bentley's recommendation. Buffalo Bill was a colorful and historical figure 
and was born in my home county, Scott County, Iowa. The commemoration of the life of William F. Cody through the issuance of a commemorative stamp would be most appropriate and would add to the knowledge of history by renewing the interest of people in this Folk Hero."

At the time of this printing, no decision has been made as to the issuance of a Buffalo Bill Cody stamp. However, the ground work has now been completed, largely through the efforts of Mr. Bentley.

Mr. Bentley, a native Iowan, attended the public schools in Waterloo and graduated in Architecture from Iowa State University, Ames. He has lived in Davenport, Iowa, since spring, 1963. He is a registered architect and Vice-President of Louis C. Kingscott \& Associates, Inc., Architects-Engineers, Davenport. He became interested in Buffalo Bill when he was quite young because his father had met Cody and was an avid fan of the Wild West. Mr. Bentley, a member of a number of local service clubs, is also a member of the Iowa Society for the Preservation of Historic Landmarks, the Save Our Landmarks Society located in Scott County, and the Lend-A-Hand Club of Davenport.

-The Editor

Pity the younger generation. They are growing up under the illusion that the only heroes are men who can hit 60 home runs in a season or weightlessly circle the world in space. They have never really heard much about the REALLY BIG HERO of the old days except from the narrow confines of television programming. This remarkable hero was just one man and he could perform the duties of herder, pony express rider, stage driver, wagon master, government scout and guide, railway contractor, Indian fighter, soldier, justice of the peace, member of the legislature, farmer, stock raiser, irrigator, miner, showman, author and publisher, and Authentic Folk Hero out of America's past.

This man is Col. William Fredrick Cody, popularly known as Buffalo Bill. This "Prince of the Plain" has been worshipped by kids of all ages for a hundred years.

Like most famous Americans of the early days, his birth and boyhood were unimposing. He was born on Feb. 26, 1846, in a frame house in Le Claire Township, Scott County, 
Iowa, and spent the first seven years of his life in this same river town. He spent many hours during his younger days talking to riverboat pilots and fishing for catfish in the Mississippi River.

Isaac Cody, Bill Cody's father, sold their home and most of their possessions as preparation for the trip to the gold fields of California. The tragic story of the events at Donner Pass during the winter of 1849 caused the Cody family to delay their westward movement for several years. In the meantime, they established a home in a rock house near McCausland, Iowa, where the elder Cody contracted to break open the prairie into farm land. This rock house is currently being restored by the Save Our Landmarks Society of Davenport, Iowa.

After several years, the Cody family moved on to Walnut Grove, Iowa, and then on to Kansas.

In Kansas, Billy refused to go to school and was something of a young hellion. A sister, Helen, told of Billy going on a boyhood binge on hard cider. He arrived home that night yelling and singing that he was going to become President of the United States. "Will never touched hard cider again after that," she said. Possibly not, but that should not be mistaken to imply that he never touched whiskey again.

When he was eleven, his father, Isaac, was stabbed to death in Kansas during an argument over the slavery issue. This left Billy as the sole bread winner for the family. He went to work for the celebrated overland freighting firm of Russels, Major and Waddell. During this time, he was supposed to have killed his first Indian.

From this job as a messenger boy, Cody went on to riding for the Pony Express. He established a record of 320 miles in less than 21 hours. Rather amazing when considering he was still only 14 years old.

He enlisted in the Civil War in 1864 on the Union side. Cody often related to his friends how that happened. "One day," he recalled, "after having been under the influence of bad whiskey, I woke to find myself a soldier in the 7th Kansas Volunteers." It was stated at the time that even though he had enlisted under the influence, that no total of incredible amounts of whiskey could bloat his stalwart figure, crimson 
his nose, or otherwise rob him of the charms that made the hearts of women flutter alarmingly.

After the Civil War, Cody took on the job that was to give him his nickname. He was hired in Kansas by Goddard Brothers food suppliers to the construction crew of the Union Pacific Railroad to kill bison. The meat would be served on the tables of the railroad workers. On this job, Cody was supreme. In 17 months, he was said to have set a record by shooting and killing 4,280 buffalo. This certainly earned him the title that was to be his-but was yet to come.

Next came William Cody the Indian Scout. He was a civilian scout with the 5th Cavalry and there is no question of his being cunning, fearless, and an excellent shot. He was chief of the scouts under General Phil Sheridon during 186869. He was one of the Big Six famous Indian scouts (Daniel Boone, Davy Crocket, Kit Carson, Jim Bridger, Wild Bill Hickock and Buffalo Bill Cody). With the help of such easterners as author Ned Buntline and newspaper publisher James Gordon Bennett, Buffalo's name and fame became known not only throughout the eastern United States, but throughout the world. He captured the imagination of the American public. They had never seen such a handsome dashing figure who rode his white horse with ease. His every move was full of dash and drama.

His following years as a scout were among the most colorful in Buffalo Bill's life. He served with the 3rd Cavalry and became known as the most cunning expert on Indians in the west. During one campaign against the Sioux, he leaped from his horse on to the mount of Chief Yellowhand, killing the chief with his knife. For his exploits against the Indians in the Platt River campaign, he was awarded the Congressional Medal of Honor.

By 1872 , his scouting days were over. Due to the urging of his eastern friends (Buntline and Bennett), Buffalo Bill went into show business. He acted in several plays written especially for him by Buntline. In 1873, Buffalo Bill opened his own show. "Buffalo Bill's Original Wild West" was chosen as the name and from the very beginning, the show was a tremendous success. It prospered for over one quarter of a century, touring the United States, Canada and Europe, where 
Cody was decorated by the royalty of half a dozen countries. Untold millions were thrilled by the Buckskinned Buffalo Bill as he shot at balls of glass from his white horse while a forty piece band blarred out "Stars and Stripes Forever."

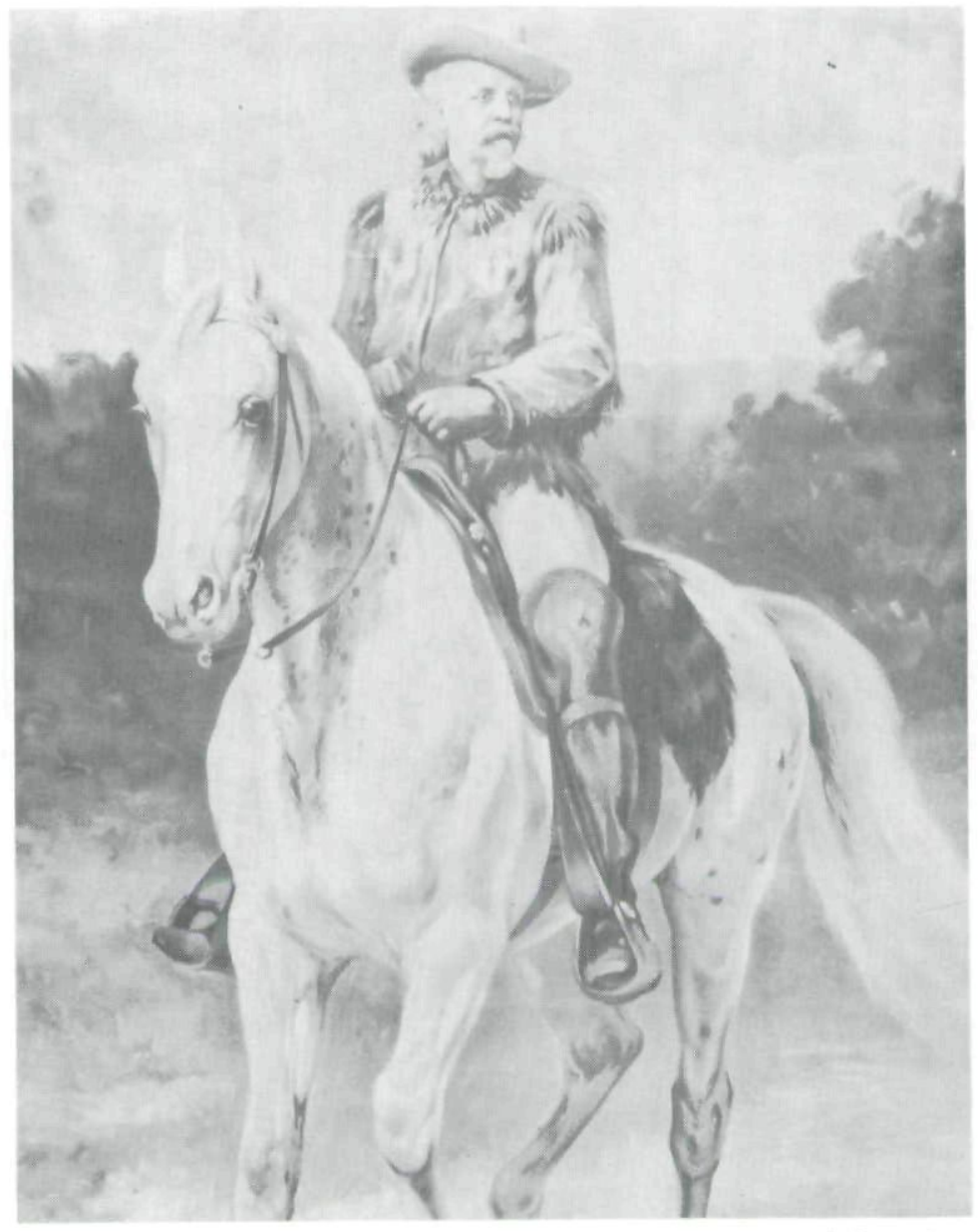

courtesy of the autbor

Buffalo Bill Cody

In the 90s, Buffalo Bill was joined by a welcome addition to his Wild West Show. She was "Little Miss Sureshot," the girl who broke 4,772 glass balls out of 5,000 that were thrown into the air. She was Annie Oakley. 
Buffalo Bill's Wild West Show was a disorganized display of rootin', tootin' and shootin'. Hundreds of Indians and cowboys always traveled with the show which was held rain or shine in an unusual type of tent. The audience was covered by cancas while the performers had the sky for a roof. Their adventurous performances included the "Robbery of the Deadwood Stage" and the "Rough Riders Raid San Juan Hill."

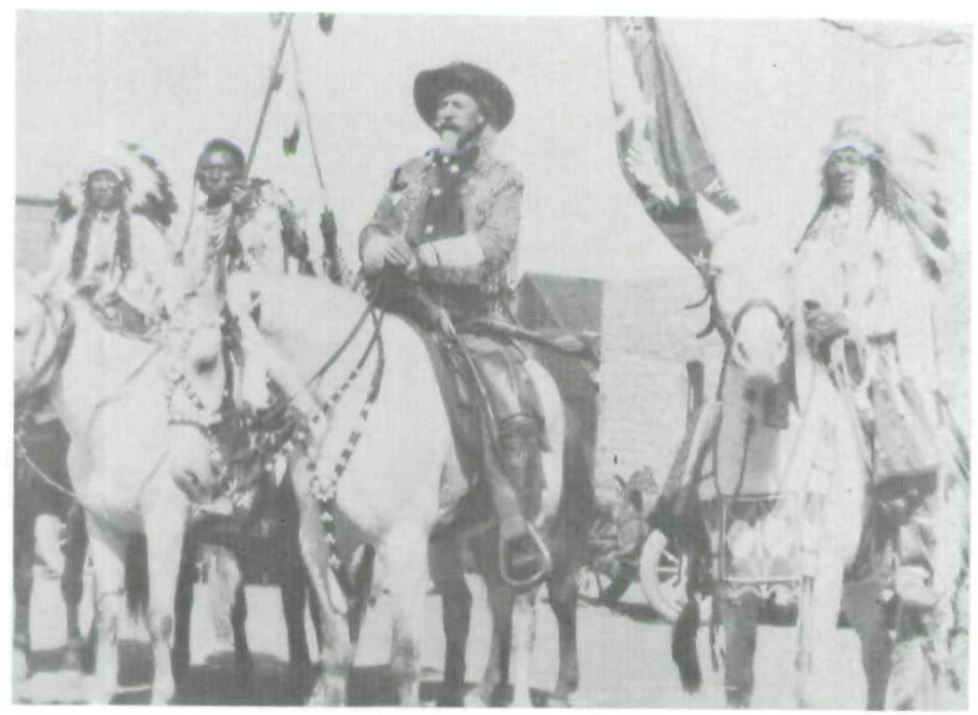

courtesy of the author

Buffalo Bill Cody and his Wild West Show

During his later years, Bill was known as a rancher in addition to his Wild West Showmanship efforts. He had three large ranches; two of his large holdings were in the Big Horn Basin in Wyoming and the third range was known as Scouts Rest Range located in North Platt, Neb. His main efforts were directed toward breeding horses that were used in the cavalry services of the English, German, Russian and United States armies. He crossed the stocky little western bronco with the larger eastern thoroughbred and developed a breed that had the best advantages of their parents.

At various times, Col. Cody served as Nebraska Justice of the Peace, a member of the Nebraska Legislature and Brig. Gen. of the Nebraska National Guard and one of the 
original founders of the Boy Scouts of America. He served as a guide for the Grand Duke Alexis of Russia. There were over 800 books written about him with many diverse stories and legends about his western exploits. He authored many books, including: "Story of Wild West" and "Camp Fire Chats" (1888) and "True Tales of the Plains" (1908).

Colonel William Fredrick Cody died Jan. 10, 1917, and is buried on Look Out Mountain near Golden, Colo. For many generations, he has been known as Buffalo Bill-Prince of the Plains. Many streets, dams, towns, museum and villages are named for Buffalo Bill, but his greatest monument lives on in the minds of the young of all ages that worship Buffalo Bill as the American Folk Hero that he is!

\section{THE CIVIL WAR DIARY OF SGT. LEVI L. HOAG}

\section{Edited by Edwin C. Bearss}

The officers and men who had enlisted in the 24th Iowa Infantry were ordered into quarter by Gov. Samuel J. Kirkwood in the period between Aug. 16 and 28, 1862. The designated rendezvous was Camp Strong, located at Muscatine, Iowa. ${ }^{1}$

One of the men of the 24th Iowa recalled:

We arrived in Muscatine at night and took the only two barracks that were completed. Company A had been there several days and had mostly built their own barrack. In a week the other companies had arrived ... We certainly had a right to be called a green regiment for I have been able to count but six out of the 982 men that when they enlisted knew how to form a company. As one company disembarked from the cars, got off their traps and the train moved on the captain said: "Gentlemen, get in two rows side by side", and when they had got, he said "Now follow me into camp", and he started off like a bellwether and they followed him to camp. $^{2}$

The ten companies which would constitute the 24th lowa

${ }^{1}$ Roster and Record of Iowa Soldiers in the War of the Rebellion-Together with Historical Sketches of Volunteer Organizations, 1861-1866, Vol. III (Des Moines, 1909), 781.

${ }^{2}$ Tipton Advertiser, August 29, 1902. 
Copyright of Annals of Iowa is the property of State of Iowa, by \& through the State Historical Society of Iowa and its content may not be copied or emailed to multiple sites or posted to a listserv without the copyright holder's express written permission. However, users may print, download, or email articles for individual use. 